\section{Synthesis and Polymerase Incorporation of $5^{\prime}$-Amino-2', $5^{\prime}$-Dideoxy-5'- $N$-Triphosphate Nucleotides}

This unit describes procedures for synthesizing $5^{\prime}$-amino- $2^{\prime}, 5^{\prime}$-dideoxy analogs of four common $2^{\prime}$-deoxynucleosides (A, C, G, and T) and corresponding nucleotides, and the efficient incorporation of the latter into DNA (Wolfe et al., 2002). Since the $5^{\prime}$-amino functional group is much more reactive than the native $5^{\prime}$-hydroxyl group, these analogs can be exploited for various applications where differential chemical reactivity between natural and modified nucleotides is desirable. Unlike modifications on diverse heterocyclic structures, the $5^{\prime}$-modification on the sugar moiety is common to all nucleotides. Consequently, the preparation of these analogs is more likely to be generalizable among all four bases, and the products are more likely to exhibit similar traits in chemical reactivity and substrate specificity.

Through the intermediacy of $5^{\prime}$-azido nucleosides $\left(\mathrm{N}_{3}\right.$-dNs), $5^{\prime}$-amino nucleosides $\left(\mathrm{NH}_{2}-\right.$ $\mathrm{dNs}$ ) are conveniently prepared through robust chemical reactions such as tosylation, azide exchange, and the Staudinger reaction. Efficient conversion of $\mathrm{NH}_{2}$-dNs to corresponding $\mathrm{NH}_{2}$-dNTPs is achieved using an elegant one-step reaction with trisodium trimetaphosphate (TMP), which was first reported in the 1970s for the preparation of $\mathrm{NH}_{2}$-dTTP (Letsinger et al., 1976a and b). By adding tris(hydroxymethyl)aminomethane (Tris) to neutralize protons generated during the reaction, the yield and stability of $\mathrm{NH}_{2}$ dNTPs have been significantly improved.

Basic Protocols 1 and 2 describe detailed procedures for displacing the $5^{\prime}$-hydroxyl group of pyrimidines and purines, respectively, with a $5^{\prime}$-azido group. Tosylation at the $5^{\prime}$-hydroxyl followed by azide exchange is applied for purines (Fig. 13.3.1; see Basic Protocol 1), whereas a one-step reaction using carbon tetrabromide, triphenylphosphine, and lithium azide is utilized for pyrimidines (Fig. 13.3.2; see Basic Protocol 2). Because it is necessary to use protected $\mathrm{dA}, \mathrm{dC}$, and $\mathrm{dG}$ for these reactions, an additional hydrolysis step is required to unmask the exocyclic amino groups. The reduction of $\mathrm{N}_{3}$-dNs to generate $\mathrm{NH}_{2}$-dNs is achieved by the Staudinger reaction (Mungal et al., 1975), and is described in Basic Protocol 3 (Fig. 13.3.3). Efficient conversion of these nucleosides to corresponding $\mathrm{NH}_{2}$-dNTPs is accomplished through a one-step reaction with TMP (Fig. 13.3.3) in the presence of Tris base (see Basic Protocol 4).

Basic Protocol 5 outlines procedures for template-directed polymerase incorporation of $\mathrm{NH}_{2}$-dNTPs. Each $\mathrm{NH}_{2}$-dNTP participates in a DNA replication reaction in place of the corresponding dNTP, either completely or partially, through its exclusive or supplementary use. Mild acid treatment of the resulting DNA generates polynucleotide fragments that arise from specific cleavage at each modified nucleotide, providing a sequence ladder for each base when analyzed by polyacrylamide gel electrophoresis.

Preparation methods for all four different $\mathrm{NH}_{2}$-dNTPs are described in the protocols. If only one analog is needed for a desired application, $\mathrm{NH}_{2}$-dTTP should be the first choice because $\mathrm{NH}_{2}$-dT is commercially available; hence, Basic Protocols 1 and 2 can be skipped. Among the remaining analogs, pyrimidine $\mathrm{NH}_{2}-\mathrm{dC}$ is somewhat more convenient to prepare than the purine analogs $\mathrm{NH}_{2}-\mathrm{dA}$ and $\mathrm{NH}_{2}-\mathrm{dG}$.
Nucleoside Phosphorylation and Related Modifications

\subsection{1}

Supplement 18 
BASIC PROTOCOL 1

$5^{\prime}-$ Amino-2, $5^{\prime}-$ Dideoxy-5'-N-

Triphosphate Nucleotides

\subsection{2}

\section{PREPARATION OF 5'-AZIDO-2' 5' $^{\prime}$-DIDEOXYPURINES}

This protocol provides streamlined procedures to prepare $\mathrm{N}_{3}-\mathrm{dA}$ and $\mathrm{N}_{3}-\mathrm{dG}$ (Fig. 13.3.1). The synthetic route involves three commonly used chemical transformations and has been previously applied for synthesizing derivatives of $\mathrm{N}_{3}-\mathrm{dA}$ and $\mathrm{N}_{3}-\mathrm{dG}$ (Mag and Engels, 1989). Starting materials $N^{4}$-benzoyl-dA and $N^{2}$-isobutyryl-dG are tosylated at the $5^{\prime}$-hydroxyl group, then reacted with lithium azide to afford $5^{\prime}$-azido derivatives. Treatment with ammonia removes the protecting groups on the exocyclic amines of $\mathrm{N}_{3}$ $\mathrm{dA}$ and $\mathrm{N}_{3}-\mathrm{dG} . \mathrm{N}_{3}-\mathrm{dG}$ is purified from the isobutyramide side product using solvent partitioning alone; however, purification of $\mathrm{N}_{3}-\mathrm{dA}$ from benzoylamide requires column chromatography.

CAUTION: All chemical reactions should be carried out in a fume hood to avoid exposure to toxic vapors.

NOTE: In order to achieve satisfactory results, anhydrous reagents should be used and experiments should be performed under an inert atmosphere.

\section{Materials}

Dry nitrogen $\left(\mathrm{N}_{2}\right)$ or argon $(\mathrm{Ar})$

$N^{6}$-Benzoyl-2'-deoxyadenosine $\left(N^{6}\right.$-Bz-dA; S.1)

Pyridine, anhydrous

$p$-Toluenesulfonyl chloride $(\mathrm{TsCl})$

$N^{2}$-Isobutyryl-2'-deoxyguanosine $\left(N^{2}-i\right.$-Bu-dG; S.5)

Ethyl acetate (EtOAc)

Saturated aqueous sodium bicarbonate $\left(\mathrm{NaHCO}_{3}\right)$

Saturated aqueous sodium chloride (brine)

Sodium sulfate $\left(\mathrm{Na}_{2} \mathrm{SO}_{4}\right)$, anhydrous

Dichloromethane $\left(\mathrm{CH}_{2} \mathrm{Cl}_{2}\right)$

Silica gel 60, 230 to 400 mesh

Methanol $(\mathrm{MeOH})$

Lithium azide $\left(\mathrm{LiN}_{3}\right)$, concentrated to dryness from a $20 \%$ solution in $\mathrm{dH}_{2} \mathrm{O}$

Dimethyl sulfoxide (DMSO), anhydrous

Ammonium hydroxide $\left(\mathrm{NH}_{4} \mathrm{OH}\right)$, concentrated aqueous solution

Chloroform $\left(\mathrm{CHCl}_{3}\right)$

Dry ice

250-, 100-, 50-, and 25-mL round-bottom flasks, oven dried

Inert atmosphere/vacuum manifold with dry ice/2-propanol trap

Balloons

Tubing adaptor

10-mL syringes

$18-G$ needles

Rotary evaporator with a built-in dry ice/2-propanol trap, attached to a vacuum pump

250-mL separatory funnels

250-mL Erlenmeyer flasks

Fritted funnels

250-mL glass chromatography columns

Test tubes

Thin-layer chromatography (TLC) plates, $0.25-\mathrm{mm}$ silica gel $60 \mathrm{~F}-254$ on glass plates

UV light source

$60^{\circ}$ and $50^{\circ} \mathrm{C}$ oil baths

Vacuum pump 


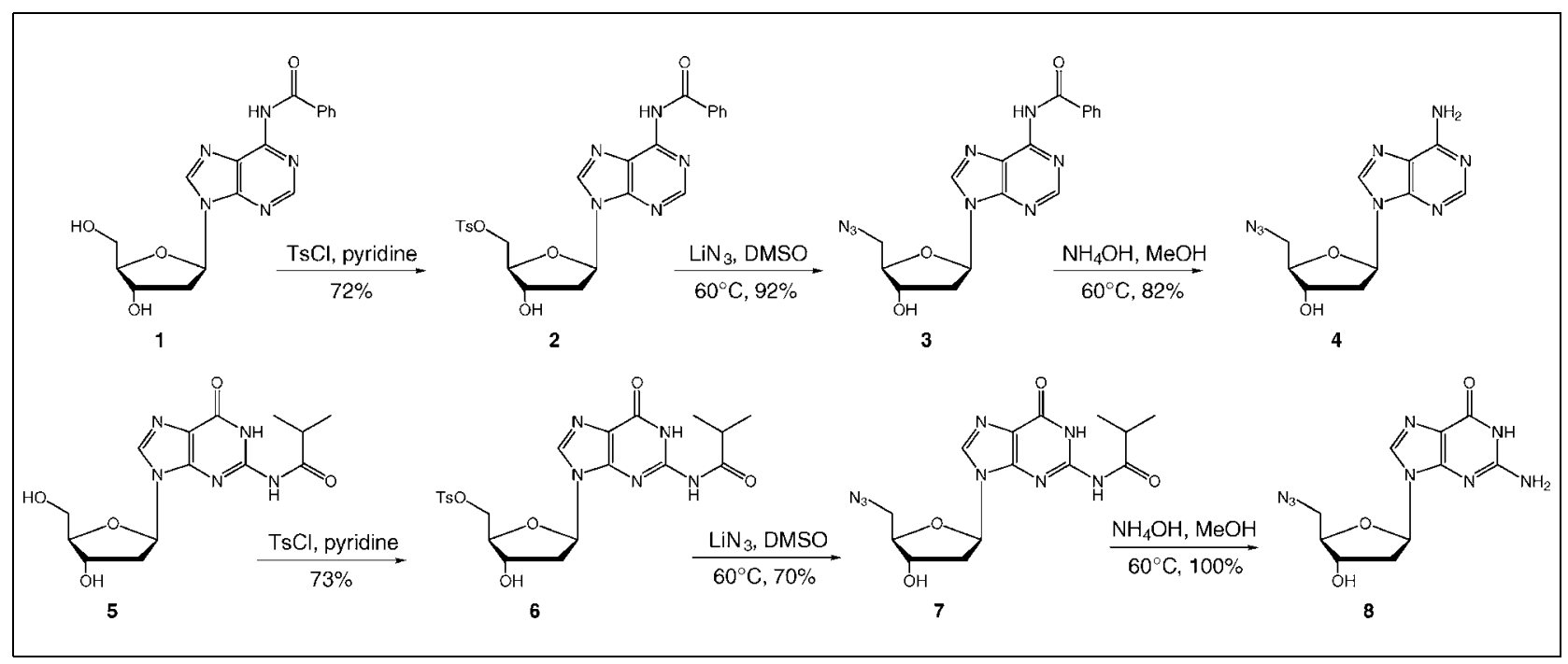

Figure 13.3.1 Preparation of $5^{\prime}$-azido-dA and $5^{\prime}$-azido-dG.

10-mL screw-capped micro-vials (e.g., Accuform vials, Kimble)

Lyophilizer

Additional reagents and equipment for column chromatography (APPENDIX $3 E$ ) and TLC (APPENDIX 3D)

\section{$5^{\prime}$-Tosylate nucleoside}

For adenosine derivative

1a. Under a $\mathrm{N}_{2}$ or Ar atmosphere, add $994 \mathrm{mg}(2.8 \mathrm{mmol})$ of $N^{6}-\mathrm{Bz}-\mathrm{dA}(\mathbf{S . 1})$ and $20 \mathrm{~mL}$ anhydrous pyridine to an oven-dried $100-\mathrm{mL}$ round-bottom flask containing $a^{3} / 4$-in. magnetic stir bar. Place the flask in an ice water bath on top of a magnetic stir plate.

$A \mathrm{~N}_{2}$ or Ar atmosphere can be provided through a tubing adaptor that connects the flask to a balloon filled with $\mathrm{N}_{2}$ or Ar, or an inert atmosphere/vacuum manifold attached to a regulated $\mathrm{N}_{2}$ or Ar tank.

2a. In a separate flask dissolve $802 \mathrm{mg}$ (4.2 mmol, 1.5 eq.) $\mathrm{TsCl}$ in $10 \mathrm{~mL}$ anhydrous pyridine under $\mathrm{N}_{2}$ or Ar.

\section{For guanosine derivative}

1b. Under $\mathrm{N}_{2}$ or Ar atmosphere, add $777 \mathrm{mg}(2.30 \mathrm{mmol})$ of $N^{2}-i$-Bu-dG (S.5) and $20 \mathrm{~mL}$ anhydrous pyridine in an oven-dried $100-\mathrm{mL}$ round-bottom flask containing $\mathrm{a}^{3} / 4$-in. magnetic stir bar. Place the flask in an ice water bath on top of a magnetic stir plate.

2b. In a separate flask dissolve $574 \mathrm{mg}(3.01 \mathrm{mmol}) \mathrm{TsCl}$ in $5 \mathrm{~mL}$ anhydrous pyridine under $\mathrm{N}_{2}$ or Ar.

3. Transfer the $\mathrm{TsCl}$ solution to a 10-mL syringe through an 18-G needle and slowly add it to the cooled, stirring nucleoside in pyridine under $\mathrm{N}_{2}$ or Ar. Allow reaction to proceed $1 \mathrm{hr}$ on ice.

\section{Work up product}

4. Remove the ice-water bath and transfer the flask to a $4^{\circ} \mathrm{C}$ refrigerator or cold room; continue stirring overnight under $\mathrm{N}_{2}$ or Ar provided through a balloon.

5. Place the reaction flask back into an ice bath, add $3 \mathrm{~mL}$ of $\mathrm{dH}_{2} \mathrm{O}$ to the mixture, and continue to stir on ice for $1 \mathrm{hr}$.

Nucleoside Phosphorylation and Related Modifications

\subsection{3}


6. Concentrate the solution to near dryness on a rotary evaporator.

7. To the residue, add $150 \mathrm{~mL}$ of EtOAc and $30 \mathrm{~mL}$ of $\mathrm{dH}_{2} \mathrm{O}$. Stir the mixture using a magnetic stir plate to partition the products between organic and aqueous phases.

8. Transfer the biphasic mixture to a $250-\mathrm{mL}$ separatory funnel to separate the organic and aqueous layers.

9. Collect the EtOAc (top) layer and wash it sequentially in the separatory funnel as

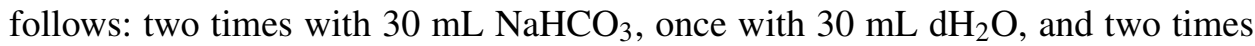
with $30 \mathrm{~mL}$ brine.

10. Collect the resulting EtOAc solution in a 250 -mL Erlenmeyer flask containing $\sim 15 \mathrm{~g}$ of anhydrous $\mathrm{Na}_{2} \mathrm{SO}_{4}$ and allow it to dry for $30 \mathrm{~min}$.

11. Remove the drying agent by filtration using a fritted funnel.

12. Concentrate the EtOAc solution on a rotary evaporator to afford a white solid residue.

13. Dissolve the residue in $\sim 2 \mathrm{~mL}$ of $\mathrm{CH}_{2} \mathrm{Cl}_{2}$ and load it onto a 100-mL chromatography column filled with $40 \mathrm{~g}$ of silica gel (APPENDIX $3 E$ ). Elute the column using $\mathrm{CH}_{2} \mathrm{Cl}_{2}$ followed by 5:95 (v/v) $\mathrm{MeOH} / \mathrm{CH}_{2} \mathrm{Cl}_{2}$ and collect fractions in test tubes.

14. Analyze all fractions by TLC (APPENDIX $3 D$ ) on silica gel plates. Develop TLC plates with 10:90 (v/v) $\mathrm{MeOH} / \mathrm{CH}_{2} \mathrm{Cl}_{2}$ and analyze them under UV illumination.

15. Combine fractions that contain the desired product $\left(R_{\mathrm{f}} \approx 0.5\right.$ for $\mathrm{dA} ; R_{\mathrm{f}} \approx 0.44$ for $\mathrm{dG})$ and concentrate to dryness using a rotary evaporator to afford the product as a light yellow or off-white foam.

$5^{\prime}-T_{s} O-N^{6}-B z-d A(S .2):$ yield $1092 \mathrm{mg}(72 \%) .{ }^{l} \mathrm{H} N M R\left(D M S O-d_{6}\right): \delta 2.32(3 \mathrm{H}, \mathrm{s}, \mathrm{Me})$, $2.37\left(1 \mathrm{H}, d d d, J=4.4,6.7,13.5 \mathrm{~Hz}, 2^{\prime} a\right), 2.85\left(1 \mathrm{H}, t d, J=6.5,13.6 \mathrm{~Hz}, 2^{\prime} b\right), 4.01(1 \mathrm{H}$, $\left.m, 4^{\prime}\right), 4.22\left(1 \mathrm{H}, d d, J=6.8,10.7 \mathrm{~Hz}, 5^{\prime} a\right), 4.31\left(1 \mathrm{H}, d d, J=3.6,10.7 \mathrm{~Hz}, 5^{\prime} b\right), 4.47$ $\left(1 \mathrm{H}, \mathrm{m}, 3^{\prime}\right), 5.57\left(1 \mathrm{H}, d, \mathrm{~J}=6.6 \mathrm{~Hz}, 3^{\prime} \mathrm{OH}\right), 6.42\left(1 \mathrm{H}, t, \mathrm{~J}=6.6 \mathrm{~Hz}, \mathrm{l}^{\prime}\right), 7.30(2 \mathrm{H}, d, \mathrm{~J}$ $=8.1 \mathrm{~Hz}, \mathrm{Ts}), 7.55(2 \mathrm{H}, \mathrm{m}, \mathrm{Ph}), 7.63(3 \mathrm{H}, \mathrm{m}, \mathrm{Ts} \& \mathrm{Ph}), 8.05(2 \mathrm{H}, d, J=7.4 \mathrm{~Hz}, \mathrm{Ph})$, $8.54(1 \mathrm{H}, \mathrm{s}, 2), 8.66(1 \mathrm{H}, \mathrm{s}, 8), 11.24(1 \mathrm{H}, \mathrm{s}, \mathrm{NH})$.

$5^{\prime}-T s O-N^{2}-i-B u-d G\left(\right.$ S.6): yield $822 \mathrm{mg}(73 \%) .{ }^{1} H$ NMR $\left(\right.$ DMSO- $\left.d_{6}\right): \delta 1.11(3 H, d, J=$ $6.8 \mathrm{~Hz}, \mathrm{Me}), d 1.12(3 \mathrm{H}, d, \mathrm{~J}=6.8 \mathrm{~Hz}, \mathrm{Me}), 2.29(1 \mathrm{H}, \mathrm{m}, \mathrm{CHMe} 2), 2.35(3 \mathrm{H}, \mathrm{s}, \mathrm{Me}(\mathrm{Ts}))$, $2.63\left(1 \mathrm{H}, t d, J=6.5,13.3 \mathrm{~Hz}, 2^{\prime} a\right), 2.74\left(1 \mathrm{H}, \mathrm{m}, 2^{\prime} b\right), 3.96\left(1 \mathrm{H}, \mathrm{m}, 4^{\prime}\right), 4.16(1 \mathrm{H}, d d, J$ $\left.=6.8,10.8 \mathrm{~Hz}, 5^{\prime} \mathrm{a}\right), 4.24\left(1 \mathrm{H}, d d, J=3.3,10.8 \mathrm{~Hz}, 5^{\prime} b\right), 4.37\left(1 \mathrm{H}, \mathrm{m}, 3^{\prime}\right), 5.50(1 \mathrm{H}, d$, $\left.J=6.6 \mathrm{~Hz}, 3^{\prime} \mathrm{OH}\right), 6.17\left(1 \mathrm{H}, t, J=6.6 \mathrm{~Hz}, \mathrm{l}^{\prime}\right), 7.32(2 \mathrm{H}, d, J=8.1 \mathrm{~Hz}, \mathrm{Ts}), 7.66(2 \mathrm{H}$, $d, J=8.2 \mathrm{~Hz}, T s), 8.06(1 \mathrm{H}, \mathrm{s}, 8), 11.56(1 \mathrm{H}, \mathrm{s}, \mathrm{NH}), 12.04(1 \mathrm{H}, d, J=5.0 \mathrm{~Hz}, \mathrm{NH})$.

\section{Convert to $5^{\prime}$-azido derivative}

16a. For dA: Transfer $1063 \mathrm{mg}$ (2.1 mmol) $5^{\prime}-\mathrm{TsO}-N^{6}-\mathrm{Bz}-\mathrm{dA}$ to a $50-\mathrm{mL}$ round-bottom flask containing a magnetic stir bar, $514 \mathrm{mg}(10.5 \mathrm{mmol}, 5$ eq. $) \mathrm{LiN}_{3}$, and $11 \mathrm{~mL}$ DMSO.

16b. For $d G$ : Transfer $811 \mathrm{mg}$ ( $1.65 \mathrm{mmol}) 5^{\prime}-\mathrm{TsO}-N^{2}-i-\mathrm{Bu}-\mathrm{dG}$ to a $25-\mathrm{mL}$ round-bottom flask containing a magnetic stir bar, $411 \mathrm{mg}(8.39 \mathrm{mmol}, 5$ eq. $) \mathrm{LiN}_{3}$, and $8 \mathrm{~mL}$ DMSO.

17. Place the flask in a $60^{\circ} \mathrm{C}$ oil bath that is heated on top of a magnetic stir plate, and stir the reaction mixture for $5 \mathrm{hr}$ while the oil bath temperature is maintained at $\sim 60^{\circ} \mathrm{C}$.

18. Concentrate the reaction mixture to $\sim 5 \mathrm{~mL}$ using a vacuum pump while heating the flask in a $50^{\circ} \mathrm{C}$ oil bath.

$5^{\prime}$-Amino-2', 5'Dideoxy-5'-N-

Triphosphate Nucleotides

19. Dissolve the residual material in $100 \mathrm{~mL}$ of EtOAc. Wash the solution with $20 \mathrm{~mL}$ $\mathrm{NaHCO}_{3}$ followed by $20 \mathrm{~mL}$ brine using a 250-mL separatory funnel. 
20. Transfer the EtOAc solution to a $250-\mathrm{mL}$ Erlenmeyer flask containing $\sim 10 \mathrm{~g}$ of anhydrous $\mathrm{Na}_{2} \mathrm{SO}_{4}$ and allow it to dry for $30 \mathrm{~min}$.

21. Collect the organic solution by filtration through a fritted funnel.

22. Concentrate the EtOAc solution on a rotary evaporator to afford a pale yellow foam product.

23. Dissolve the crude product in $\sim 2 \mathrm{~mL}$ of $\mathrm{CH}_{2} \mathrm{Cl}_{2}$ and apply it to a $100-\mathrm{mL}$ chromatography column filled with $40 \mathrm{~g}$ of silica gel. Elute the column with $\mathrm{CH}_{2} \mathrm{Cl}_{2}$ followed by 5:95 (v/v) $\mathrm{MeOH} / \mathrm{CH}_{2} \mathrm{Cl}_{2}$.

24. Analyze all fractions by TLC on silica gel, developing the TLC plates with 10:90 (v/v) $\mathrm{MeOH} / \mathrm{CH}_{2} \mathrm{Cl}_{2}$.

25. Collect the fractions containing the desired product $\left(R_{\mathrm{f}} \approx 0.4\right.$ for $\mathrm{dA} ; R_{\mathrm{f}} \approx 0.37$ for $\mathrm{dG})$ and concentrate to dryness.

$5^{\prime}-N_{3}-N^{6}-B z-d A(S .3):$ yield $764 m g(92 \%) .{ }^{1} H$ NMR $\left(D M S O-d_{6}\right): \delta 2.40(1 H, d d d, J=$ 4.1, 6.6, 13.4 Hz, 2' a), 2.97 (1H, $\left.t d, J=6.6,13.3 \mathrm{~Hz}, 2^{\prime} b\right), 3.53(1 \mathrm{H}, \mathrm{dd}, \mathrm{J}=3.9,13.1 \mathrm{~Hz}$, $\left.5^{\prime} a\right), 3.65\left(1 \mathrm{H}, d d, J=7.0,13.0 \mathrm{~Hz}, 5^{\prime} b\right), 4.01\left(1 \mathrm{H}, \mathrm{m}, 4^{\prime}\right), 4.48\left(1 \mathrm{H}, \mathrm{m}, 3^{\prime}\right), 5.54(1 \mathrm{H}$, $\left.d, J=3.7 \mathrm{~Hz}, 3^{\prime} \mathrm{OH}\right), 6.51\left(1 \mathrm{H}, t, J=6.7 \mathrm{~Hz}, \mathrm{l}^{\prime}\right), 7.54(2 \mathrm{H}, m, P h), 7.64(1 \mathrm{H}, t, J=7.3$ $\mathrm{Hz}, \mathrm{Ph}), 8.03(2 \mathrm{H}, \mathrm{d}, \mathrm{J}=7.5 \mathrm{~Hz}, \mathrm{Ph}), 8.69(1 \mathrm{H}, \mathrm{s}, 2), 8.76(1 \mathrm{H}, \mathrm{s}, 8), 11.20(1 \mathrm{H}, \mathrm{s}, \mathrm{NH})$.

$5^{\prime}-N_{3}-N^{2}-i-B u-d G(S .7):$ yield $419 m g(70 \%) .{ }^{1} H$ NMR $\left(D M S O-d_{6}\right): \delta 1.11(6 H, d, J=$ $6.8 \mathrm{~Hz}, \mathrm{Me}), 2.31\left(1 \mathrm{H}, \mathrm{ddd}, \mathrm{J}=3.7,6.1,13.3 \mathrm{~Hz}, 2^{\prime} a\right), 2.75\left(2 \mathrm{H}, \mathrm{m}, \mathrm{CHMe}_{2} \& 2^{\prime} b\right), 3.50$ $\left(1 \mathrm{H}, d d, J=4.2,13.1 \mathrm{~Hz}, 5^{\prime} a\right), 3.58\left(1 \mathrm{H}, d d, J=6.8,13.1 \mathrm{~Hz}, 5^{\prime} b\right), 3.94\left(1 \mathrm{H}, \mathrm{m}, 4^{\prime}\right)$, $4.34\left(1 H, m, 3^{\prime}\right), 5.48\left(1 H, d, J=3.7 H z, 3^{\prime} O H\right), 6.24\left(1 H, t, J=6.8 H z, l^{\prime}\right), 8.24(1 H$, $s, 8), 11.64(1 H, s, N H), 12.07(1 H, d, J=4.7 \mathrm{~Hz}, \mathrm{NH})$.

\section{Deprotect exocyclic amine}

26a. For dA: Transfer $599 \mathrm{mg}(1.6 \mathrm{mmol})$ of $5^{\prime}-\mathrm{N}_{3}-N^{6}-\mathrm{Bz}-\mathrm{dA}$ to a $10-\mathrm{mL}$ screw-capped micro-vial containing a magnetic stir bar and add $4 \mathrm{~mL}$ of $\mathrm{MeOH}$ to dissolve the solid.

26b. For $d G$ : Transfer $409 \mathrm{mg}(1.13 \mathrm{mmol})$ of $5^{\prime}-\mathrm{N}_{3}-N^{6}-i-\mathrm{Bu}-\mathrm{dG}$ to a $10-\mathrm{mL}$ screwcapped micro-vial containing a magnetic stir bar and add $4 \mathrm{~mL}$ of $\mathrm{MeOH}$ to dissolve the solid.

27. Transfer $2 \mathrm{~mL}$ (half) of the resulting solution to a second 10-mL screw-capped micro-vial containing a magnetic stir bar.

28. Add $3 \mathrm{~mL}$ of concentrated $\mathrm{NH}_{4} \mathrm{OH}$ to each micro-vial, place the vials in a $\sim 60^{\circ} \mathrm{C}$ oil bath on top of a magnetic stir plate, and stir overnight (13 to $15 \mathrm{hr}$ ) at $\sim 60^{\circ} \mathrm{C}$.

29. Cool the vials on ice. Transfer the reaction mixtures to a round-bottom flask and concentrate to dryness using a rotary evaporator to afford a light yellow or off-white solid residue.

30. Dissolve the crude product in $60 \mathrm{~mL}$ of $\mathrm{dH}_{2} \mathrm{O}$, and extract the resulting aqueous solution five times with $5 \mathrm{~mL} \mathrm{CHCl}_{3}$ using a separatory funnel. Collect the aqueous (top) layer and save the $\mathrm{CHCl}_{3}$ extracts.

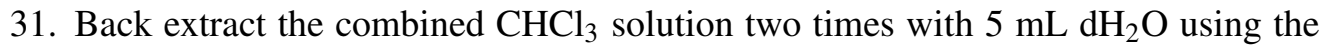
separatory funnel. Collect the aqueous solutions.

For $\mathrm{N}_{3}-d A$

32a. Combine all the aqueous solutions in a $250-\mathrm{mL}$ round-bottom flask and freeze on dry ice. Concentrate to dryness using a lyophilizer.

Nucleoside Phosphorylation and Related Modifications

\subsection{5}

Supplement 18 
33a. Dissolve the crude $\mathrm{N}_{3}$-dA product in $\mathrm{CH}_{2} \mathrm{Cl}_{2}$ and purify on a chromatography column containing $40 \mathrm{~g}$ of silica gel. Elute the column with 2:98 to 10:90 (v/v) $\mathrm{MeOH} / \mathrm{CH}_{2} \mathrm{Cl}_{2}$.

34a. Analyze all fractions by TLC, developing the silica gel plates with 10:90 (v/v) $\mathrm{MeOH} / \mathrm{CH}_{2} \mathrm{Cl}_{2}$.

35a. Collect the fractions containing the desired product $\left(R_{\mathrm{f}} \approx 0.2\right)$ and concentrate it to dryness to afford the product as light yellow foam.

$5^{\prime}$-Azido-2', $5^{\prime}$-dideoxyadenosine ( $\mathrm{N}_{3}-d A ;$ S.4): yield $350 \mathrm{mg}(82 \%) .{ }^{1} \mathrm{H} N M R$ (DMSO$\left.d_{6}\right): \delta 2.30\left(1 \mathrm{H}, d d d, J=3.7,6.4,13.3 \mathrm{~Hz}, 2^{\prime} a\right), 2.92\left(1 \mathrm{H}, t d, J=6.7,13.4 \mathrm{~Hz}, 2^{\prime} b\right)$, $3.48\left(1 \mathrm{H}, d d d, J=3.9,12.9 \mathrm{~Hz}, 5^{\prime} a\right), 3.65\left(1 \mathrm{H}, d d d, J=7.3,12.9 \mathrm{~Hz}, 5^{\prime} b\right), 3.96(1 \mathrm{H}, \mathrm{m}$, $\left.4^{\prime}\right), 4.41\left(1 \mathrm{H}, \mathrm{m}, 3^{\prime}\right), 5.48\left(1 \mathrm{H}, \mathrm{d}, \mathrm{J}=4.0 \mathrm{~Hz}, 3^{\prime} \mathrm{OH}\right), 6.37\left(1 \mathrm{H}, t, J=6.9 \mathrm{~Hz}, \mathrm{l}^{\prime}\right), 7.29$ $\left(2 \mathrm{H}, \mathrm{s}, \mathrm{NH}_{2}\right), 8.14(1 \mathrm{H}, \mathrm{s}, 2), 8.33(1 \mathrm{H}, \mathrm{s}, 8)$.

For $N_{3}-d G$

$32 \mathrm{~b}$. Combine all the aqueous solutions in a $250-\mathrm{mL}$ round-bottom flask and freeze on dry ice. Concentrate to dryness using a lyophilizer to afford the product as a white solid. Use this material to prepare $\mathrm{NH}_{2}-\mathrm{dG}$ without further purification.

$5^{\prime}$-Azido-2', $5^{\prime}$-dideoxyguanosine ( $\mathrm{N}_{3}$-dG; S.8): yield $340 \mathrm{mg}(100 \%)$. ${ }^{\mathrm{I}} \mathrm{H}$ NMR (DMSO$\left.d_{6}\right): \delta 2.22\left(1 \mathrm{H}, d d d, J=3.2,6.1,13.2 \mathrm{~Hz}, 2^{\prime} a\right), 2.70\left(1 \mathrm{H}, t d, J=6.3,13.5 \mathrm{~Hz}, 2^{\prime} b\right), 3.46$ $\left(1 \mathrm{H}, d d, J=4.2,13.0 \mathrm{~Hz}, 5^{\prime} a\right), 3.61\left(1 \mathrm{H}, d d, J=7.2,13.0 \mathrm{~Hz}, 5^{\prime} b\right), 3.91\left(1 \mathrm{H}, \mathrm{m}, 4^{\prime}\right)$, $4.29\left(1 \mathrm{H}, \mathrm{m}, 3^{\prime}\right), 5.44\left(1 \mathrm{H}, \mathrm{br}, 3^{\prime} \mathrm{OH}\right), 6.14\left(1 \mathrm{H}, t, \mathrm{~J}=6.9 \mathrm{~Hz}, \mathrm{l}^{\prime}\right), 6.53\left(2 \mathrm{H}, \mathrm{brs}, \mathrm{NH}_{2}\right)$, $7.90(1 \mathrm{H}, \mathrm{s}, 8), 9.48(1 \mathrm{H}, \mathrm{brs}, \mathrm{NH})$.

BASIC PROTOCOL 2

$5^{\prime}$-Amino-2', 5'Dideoxy-5' $-N$ -

Triphosphate Nucleotides

\subsection{6}

\section{PREPARATION OF 5'-AZIDO-2' 5' $^{\prime}$-DIDEOXYPYRIMIDINES}

$\mathrm{N}_{3}$-dC is prepared based on a one-step azidation procedure (Fig. 13.3.2) that utilizes a mixture of triphenylphosphine, carbon tetrabromide, and lithium azide (Yamamoto et al., 1980). This same procedure is applicable for the preparation of $\mathrm{N}_{3}$-dT, although the latter is commercially available. An extra aqueous ammonia deprotection step is used in the synthesis of $\mathrm{N}_{3}$-dC to remove the exocyclic amino protection that is required during the azidation procedure.

CAUTION: All chemical reactions should be carried out in a fume hood to avoid toxic vapors.

NOTE: In order to achieve satisfactory results, anhydrous reagents should be used and experiments should be performed under an inert atmosphere.

\section{Materials}

$N^{4}$-Benzoyl-2'-deoxycytidine $\left(N^{4}\right.$-Bz-dC; S.9)

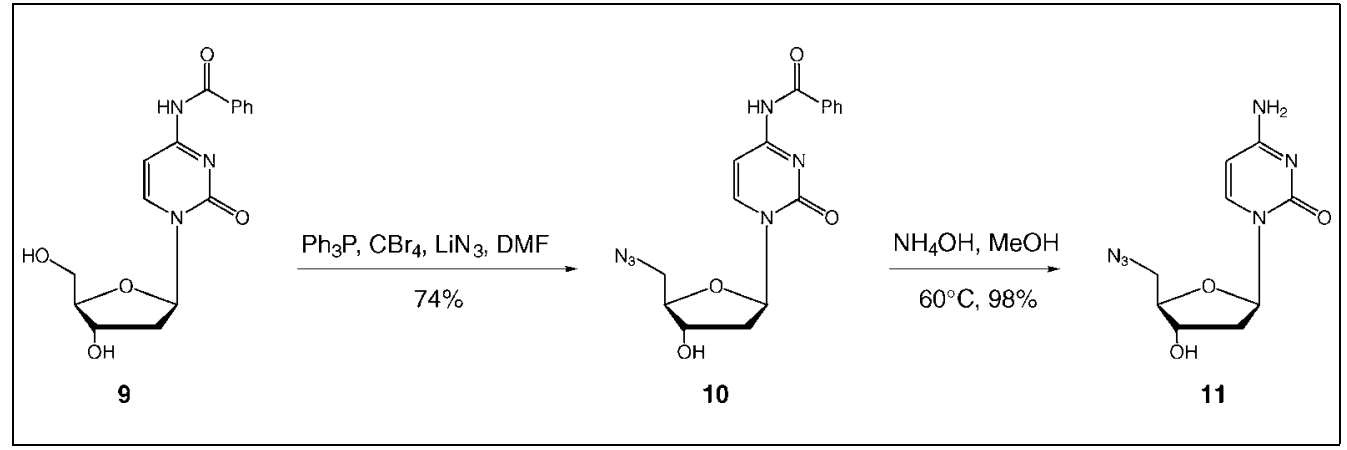

Figure 13.3.2 Preparation of 5'-azido-dC. 
Dimethylformamide (DMF), anhydrous

Lithium azide $\left(\mathrm{LiN}_{3}\right)$, concentrated to dryness from a $20 \%$ solution in $\mathrm{dH}_{2} \mathrm{O}$

Triphenylphosphine $\left(\mathrm{Ph}_{3} \mathrm{P}\right)$

Dry nitrogen $\left(\mathrm{N}_{2}\right)$ or argon $(\mathrm{Ar})$

Carbon tetrabromide $\left(\mathrm{CBr}_{4}\right)$

Silica gel 60, 230 to 400 mesh

Chloroform $\left(\mathrm{CHCl}_{3}\right)$

Methanol $(\mathrm{MeOH})$

Dichloromethane $\left(\mathrm{CH}_{2} \mathrm{Cl}_{2}\right)$

Pyridine, anhydrous

Ammonium hydroxide $\left(\mathrm{NH}_{4} \mathrm{OH}\right)$, concentrated aqueous solution

Ethyl acetate (EtOAc)

Diethyl ether $\left(\mathrm{Et}_{2} \mathrm{O}\right)$

Dry ice

25-, 100-, and 250-mL round-bottom flasks, oven dried

Rotary evaporator with dry ice/2-propanol trap, attached to a vacuum pump

Vacuum pump

Inert atmosphere/vacuum manifold with dry ice/2-propanol trap

Tubing adaptor

Balloons

250-mL glass chromatography column

Thin-layer chromatography (TLC) plates, $0.25-\mathrm{mm}$ silica gel $60 \mathrm{~F}-254$ on glass

UV light source

10-mL screw-capped micro-vials (e.g., Accuform vials, Kimble)

$60^{\circ} \mathrm{C}$ oil bath

100-mL separatory funnel

Lyophilizer

Additional reagents and equipment for column chromatography (APPENDIX $3 E$ ) and TLC (APPENDIX 3D)

\section{Convert to $5^{\prime}$-azido derivative}

1. Mix $603 \mathrm{mg}(1.82 \mathrm{mmol}) N^{4}-\mathrm{Bz}-\mathrm{dC}(\mathbf{S . 9})$ and $5 \mathrm{~mL}$ of anhydrous DMF in a $25-\mathrm{mL}$ round-bottom flask and concentrate the solution to dryness using a rotary evaporator.

2. Add a $1 / 2$-in. magnetic stir bar to the flask and attach the flask to a vacuum pump through a vacuum manifold to remove residual solvent.

3. Add $272 \mathrm{mg} \mathrm{LiN}_{3}$ (5.56 mmol, 3 eq.), $621 \mathrm{mg} \mathrm{Ph} 3 \mathrm{P}$ (2.37 mmol, 1.3 eq.), and $10 \mathrm{~mL}$ anhydrous DMF to the flask under a $\mathrm{N}_{2}$ or Ar atmosphere. Stir the mixture on a magnetic stir plate for a few minutes to afford a slightly cloudy solution $\left(\mathrm{LiN}_{3}\right.$ does not dissolve completely).

$A N_{2}$ or Ar atmosphere can be provided through a tubing adaptor that connects the flask to a balloon filled with $\mathrm{N}_{2}$ or Ar, or an inert atmosphere/vacuum manifold attached to a regulated $\mathrm{N}_{2}$ or Ar tank.

4. Add $789 \mathrm{mg}$ ( $2.34 \mathrm{mmol}, 1.3$ eq.) $\mathrm{CBr}_{4}$ to the solution and stir the mixture overnight (19 hr) at room temperature.

5. Remove DMF using a rotary evaporator to afford an orange residue.

6. Purify the residue using a $250-\mathrm{mL}$ chromatography column containing $40 \mathrm{~g}$ of silica (APPENDIX 3E). Elute the column with $\mathrm{CHCl}_{3}$ followed by $4: 100$ (v/v) $\mathrm{MeOH} / \mathrm{CHCl}_{3}$.

7. Analyze all fractions by TLC (APPENDIX $3 D)$ on silica gel plates. Develop TLC plates with 10:90 (v/v) $\mathrm{MeOH} / \mathrm{CH}_{2} \mathrm{Cl}_{2}$. 
8. Collect the fractions containing the major product $\left(R_{\mathrm{f}} \approx 0.4\right)$ and concentrate to dryness to afford the product as a white foam.

$5^{\prime}-N_{3}-N^{4}-B z-d C$ (S.10): yield $477 \mathrm{mg}(74 \%) .{ }^{1} H$ NMR $\left(D M S O-d_{6}\right): \delta 2.19(1 H, t d, J=$ $\left.6.4,13.2 \mathrm{~Hz}, 2^{\prime} a\right), 2.29\left(1 \mathrm{H}, d d d, J=4.5,6.2,13.2 \mathrm{~Hz}, 2^{\prime} b\right), 3.60(1 \mathrm{H}, d d, J=4.0,13.2$

$\left.\mathrm{Hz}, 5^{\prime} \mathrm{a}\right), 3.67\left(1 \mathrm{H}, d d, J=6.4,13.2 \mathrm{~Hz}, 5^{\prime} b\right), 3.94\left(1 \mathrm{H}, \mathrm{m}, 4^{\prime}\right), 4.17\left(1 \mathrm{H}, \mathrm{m}, 3^{\prime}\right), 5.48$ $\left(1 \mathrm{H}, d, J=4.3 \mathrm{~Hz}, 3^{\prime} \mathrm{OH}\right), 6.19\left(1 \mathrm{H}, t, J=6.4 \mathrm{~Hz}, \mathrm{l}^{\prime}\right), 7.39(1 \mathrm{H}, \mathrm{brs}, 5), 7.50(2 \mathrm{H}, \mathrm{m}$, $P h), 7.61(1 \mathrm{H}, t, J=7.3 \mathrm{~Hz}, \mathrm{Ph}), 7.99(2 \mathrm{H}, d, J=7.5 \mathrm{~Hz}, \mathrm{Ph}), 8.18(1 \mathrm{H}, d, J=7.2 \mathrm{~Hz}$, 6), $11.29(1 \mathrm{H}, \mathrm{s}, \mathrm{NH})$.

\section{Deprotect exocyclic amine}

9. Transfer $454 \mathrm{mg}$ (1.27 mmol) $5^{\prime}-\mathrm{N}_{3}-N^{4}-\mathrm{Bz}-\mathrm{dC}$ to a $10-\mathrm{mL}$ screw-capped micro-vial containing a magnetic stir bar. Add $5 \mathrm{~mL}$ pyridine and $5 \mathrm{~mL}$ concentrated $\mathrm{NH}_{4} \mathrm{OH}$.

10. Stir the resulting mixture to dissolve the solids, and then transfer $5 \mathrm{~mL}$ of the solution to another $10-\mathrm{mL}$ screw-capped micro-vial containing a magnetic stir bar.

11. Place both vials in a $\sim 60^{\circ} \mathrm{C}$ oil bath heated on top of a magnetic stir plate and stir at $\sim 60^{\circ} \mathrm{C}$ for $8.5 \mathrm{hr}$.

12. Cool the vials on ice, transfer the reaction mixture to a $100-\mathrm{mL}$ round-bottom flask, and concentrate it to dryness using a rotary evaporator.

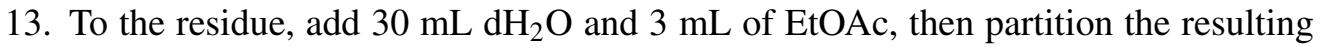
mixture in a $100-\mathrm{mL}$ separatory funnel.

14. Collect the aqueous solution and extract it three times with $3 \mathrm{~mL} \mathrm{Et}_{2} \mathrm{O}$ followed by two times with $5 \mathrm{~mL}$ of 1:2(v/v) EtOAc/Et ${ }_{2} \mathrm{O}$.

15. Freeze the aqueous solution on dry ice and concentrate it using a lyophilizer to afford the product as a light yellow solid.

$5^{\prime}$-Azido-2', $5^{\prime}$-dideoxycytosine ( $\mathrm{N}_{3}-d C$; S.11): yield $316 \mathrm{mg}$ (98\%). ${ }^{1} \mathrm{H}$ NMR (DMSO$\left.d_{6}\right): \delta 2.07\left(2 \mathrm{H}, \mathrm{m}, 2^{\prime}\right), 3.51\left(1 \mathrm{H}, d d, J=4.4,13.1 \mathrm{~Hz}, 5^{\prime} \mathrm{a}\right), 3.56(1 \mathrm{H}, d d, J=6.2,13.1$ $\left.\mathrm{Hz}, 5^{\prime} b\right), 3.83\left(1 \mathrm{H}, \mathrm{m}, 4^{\prime}\right), 4.12\left(1 \mathrm{H}, \mathrm{m}, 3^{\prime}\right), 5.38\left(1 \mathrm{H}, \mathrm{d}, \mathrm{J}=4.3 \mathrm{~Hz}, 3^{\prime} \mathrm{OH}\right), 5.73(1 \mathrm{H}, \mathrm{d}$, $J=7.4 \mathrm{~Hz}, 5), 6.21\left(1 \mathrm{H}, t, J=6.8 \mathrm{~Hz}, l^{\prime}\right), 7.16(1 \mathrm{H}, \mathrm{brs}, \mathrm{NH}), 7.20(1 \mathrm{H}, \mathrm{brs}, \mathrm{NH}), 7.60$ $(1 \mathrm{H}, d, J=7.4 \mathrm{~Hz}, 6)$.

BASIC PROTOCOL 3

$5^{\prime}$-Amino-2', $\mathbf{5}^{\prime}-$ Dideoxy-5' $-N$ -

Triphosphate Nucleotides

\subsection{8}

\section{PREPARATION OF 5'-AMINO-2' , $^{\prime}$-DIDEOXYNUCLEOSIDES}

This protocol describes a common procedure useful for the preparation of all four $5^{\prime}$-amino-2',5'-dideoxynucleosides $\left(\mathrm{NH}_{2}\right.$-dNs) from corresponding $5^{\prime}$-azido derivatives (Fig. 13.3.3). Treatment with triphenylphosphine $\left(\mathrm{Ph}_{3} \mathrm{P}\right)$ followed by hydrolysis with aqueous ammonia quantitatively converts $5^{\prime}$-azido nucleosides to $5^{\prime}$-amino nucleosides (Wolfe et al., 2002). The protocol uses the preparation of $\mathrm{NH}_{2}-\mathrm{dG}$ as an example, but is also applicable for the synthesis of $\mathrm{NH}_{2}-\mathrm{dA}$ and $\mathrm{NH}_{2}$-dC. Specific experimental conditions for each of these analogs are listed in Table 13.3.1. $\mathrm{NH}_{2}$-dT is commercially available and is not described here (interested readers are referred to Tetzlaff et al., 1998).

\section{Materials}

$\mathrm{N}_{3}-\mathrm{dA}, \mathrm{N}_{3}-\mathrm{dG}$, and $\mathrm{N}_{3}-\mathrm{dC}$ (see Basic Protocols 1 and 2)

Pyridine, anhydrous

Triphenylphosphine $\left(\mathrm{Ph}_{3} \mathrm{P}\right)$

Dry nitrogen $\left(\mathrm{N}_{2}\right)$ or argon $(\mathrm{Ar})$

Ammonium hydroxide $\left(\mathrm{NH}_{4} \mathrm{OH}\right)$, concentrated aqueous solution

Ethyl acetate (EtOAc)

25-mL round-bottom flask

Rotary evaporator with dry ice/2-propanol trap, attached to a vacuum pump 


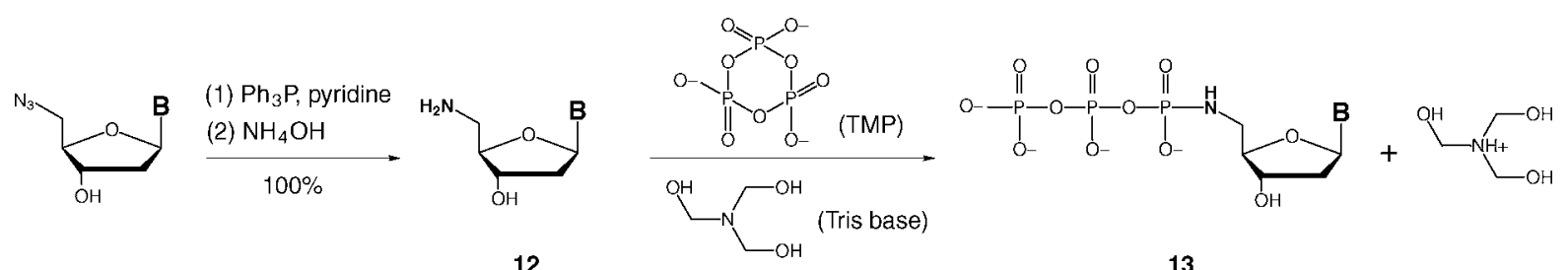

12

13

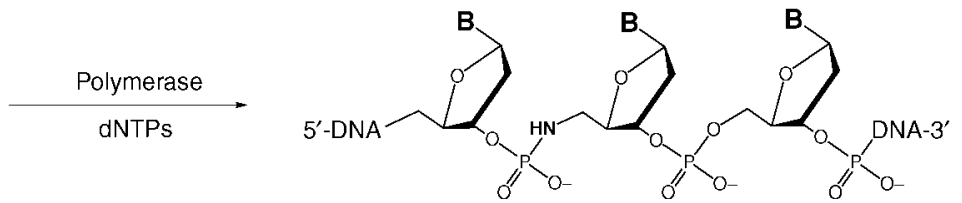

Figure 13.3.3 Preparation of 5'-amino-dNs, $5^{\prime}$-amino-dNTPs, and an oligonucleotide containing a single P-N linkage.

Table 13.3.1 Synthesis Conditions Used for Each $\mathrm{NH}_{2}-\mathrm{dN}^{a}$

\begin{tabular}{lllll}
\hline & $\mathrm{N}_{3}$-dN (step 1) & $\mathrm{Ph}_{3} \mathrm{P} / \mathrm{Pyr}$ (step 3) & $\mathrm{NH}_{4} \mathrm{OH}$ (steps 4 to 5) & $\mathrm{H}_{2} \mathrm{O}$ (step 6) \\
\hline $\mathrm{NH}_{2}$-dA & $0.12 \mathrm{mmol}$ & $0.38 \mathrm{mmol} / 1 \mathrm{~mL} / 7 \mathrm{hr}$ & $0.2 \mathrm{~mL} / 15 \mathrm{hr} \mathrm{RT} / 1 \mathrm{hr} 55^{\circ} \mathrm{C}$ & $5 \mathrm{~mL}$ \\
$\mathrm{NH}_{2}-\mathrm{dC}$ & $0.31 \mathrm{mmol}$ & $0.93 \mathrm{mmol} / 2 \mathrm{~mL} / 7 \mathrm{hr}$ & $0.2 \mathrm{~mL} / 15 \mathrm{hr} \mathrm{RT}$ & $5 \mathrm{~mL}$ \\
$\mathrm{NH}_{2}-\mathrm{dG}$ & $0.14 \mathrm{mmol}$ & $0.43 \mathrm{mmol} / 1 \mathrm{~mL} / 5 \mathrm{hr}$ & $0.3 \mathrm{~mL} / 17 \mathrm{hr} \mathrm{RT} / 1 \mathrm{hr} 55^{\circ} \mathrm{C}$ & $6 \mathrm{~mL}$ \\
\hline
\end{tabular}

${ }^{a}$ Pyr, pyridine; RT, room temperature.

Inert atmosphere/vacuum manifold with dry ice/2-propanol trap

Tubing adaptor

Balloon

$55^{\circ} \mathrm{C}$ oil bath

Fritted funnel

Lyophilizer

1. Place $40 \mathrm{mg}(0.14 \mathrm{mmol}) \mathrm{N}_{3}-\mathrm{dG}(\mathbf{S . 8})$ in a $25-\mathrm{mL}$ round-bottom flask (also see Table 13.3.1).

2. Add $2 \mathrm{~mL}$ anhydrous pyridine and concentrate it to dryness on a rotary evaporator. Repeat.

3. Add 3 molar equiv. ( $111 \mathrm{mg}, 0.43 \mathrm{mmol}$ ) $\mathrm{Ph}_{3} \mathrm{P}, 1 \mathrm{~mL}$ anhydrous pyridine, and a $1 / 2$-in. magnetic stir bar to the flask. Under a $\mathrm{N}_{2}$ or Ar atmosphere, stir the reaction mixture using a magnetic stir plate $5 \mathrm{hr}$ at room temperature.

$A N_{2}$ or Ar atmosphere can be provided through a tubing adaptor that connects the flask to a balloon filled with $\mathrm{N}_{2}$ or Ar, or an inert atmosphere/vacuum manifold attached to a regulated $\mathrm{N}_{2}$ or Ar tank.

4. Add $0.3 \mathrm{~mL}$ concentrated $\mathrm{NH}_{4} \mathrm{OH}$ and stir overnight (17 hr) at room temperature.

5. Place the flask in a $55^{\circ} \mathrm{C}$ oil bath on top of a magnetic stir plate and continue to stir for $1 \mathrm{hr}$.

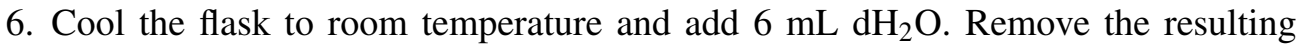
precipitate using a fritted funnel and rinse with $1 \mathrm{~mL} \mathrm{dH_{2 }} \mathrm{O}$.

7. Collect the filtrate (aqueous solution) and extract it with $10 \mathrm{~mL}$ EtOAc.

8. Concentrate the resulting aqueous solution to dryness using a lyophilizer to afford a crude product which can be used in Basic Protocol 4 without further purification.

Nucleoside Phosphorylation and Related Modifications

13.3.9 
$5^{\prime}$-Amino-2', $5^{\prime}$-dideoxyguanosine $\left(\mathrm{NH}_{2}-d G\right.$; S.12): yield $50 \mathrm{mg}(100 \%)$ as pale yellow solid. ${ }^{1} \mathrm{H}$ NMR (DMSO-d $)$ : $\delta 2.19\left(1 \mathrm{H}, \mathrm{m}, \mathrm{2}^{\prime} \mathrm{a}\right), 2.57\left(1 \mathrm{H}, t \mathrm{~d}, \mathrm{~J}=6.6,13.4 \mathrm{~Hz}, 2^{\prime} b\right)$, $2.82\left(2 \mathrm{H}\right.$, brs, $\left.5^{\prime}\right), 3.79\left(1 \mathrm{H}\right.$, brs, $\left.4^{\prime}\right), 4.37\left(1 \mathrm{H}\right.$, brs, $\left.3^{\prime}\right), 5.76\left(3 \mathrm{H}, \mathrm{brs}, \mathrm{NH}_{2}\right.$, \& $\left.3^{\prime} \mathrm{OH}\right)$, $6.11\left(1 \mathrm{H}, t d, J=6.9 \mathrm{~Hz}, \mathrm{l}^{\prime}\right), 6.90\left(2 \mathrm{H}, \mathrm{brs}, \mathrm{NH}_{2}\right), 7.88(1 \mathrm{H}, \mathrm{s}, 8)$.

$5^{\prime}$-Amino-2', $5^{\prime}$-dideoxyadenosine $\left(\mathrm{NH}_{2}-d A ;\right.$ S.12): yield $63 \mathrm{mg}(>100 \%)$ as white solid. ${ }^{1} \mathrm{H} \mathrm{NMR}\left(\mathrm{DMSO}-d_{6}\right): \delta 2.23\left(1 \mathrm{H}, d d d, J=3.3,6.1,13.1 \mathrm{~Hz}, 2^{\prime} a\right), 2.80\left(3 \mathrm{H}, \mathrm{m}, 2^{\prime} b\right.$ \& $\left.5^{\prime}\right), 3.82\left(1 \mathrm{H}, \mathrm{m}, 4^{\prime}\right), 4.42\left(1 \mathrm{H}, \mathrm{m}, 3^{\prime}\right), 5.70\left(3 \mathrm{H}, \mathrm{br}, \mathrm{NH}_{2} \& 3^{\prime} \mathrm{OH}\right), 6.32(1 \mathrm{H}, t, J=6.6$ $\left.\mathrm{Hz}, \mathrm{l}^{\prime}\right), 7.29\left(2 \mathrm{H}\right.$, brs, $\left.\mathrm{NH}_{2}\right), 8.14(\mathrm{lH}, \mathrm{s}, 2), 8.35(1 \mathrm{H}, \mathrm{s}, 8)$.

$5^{\prime}$-Amino-2', $5^{\prime}$-dideoxycytosine $\left(\mathrm{NH}_{2}-\mathrm{dC}\right.$; S.12): yield $104 \mathrm{mg}(>100 \%)$ as light brown foam. ${ }^{1} \mathrm{H} \mathrm{NMR}\left(\mathrm{DMSO}-\mathrm{d}_{6}\right): \delta 1.95\left(1 \mathrm{H}, \mathrm{td}, \mathrm{J}=6.6,13.4 \mathrm{~Hz}, 2^{\prime} \mathrm{a}\right), 2.09(1 \mathrm{H}, \mathrm{ddd}, \mathrm{J}=$ 3.9, 5.7, $\left.13.2 \mathrm{~Hz}, 2^{\prime} b\right), 2.75\left(2 \mathrm{H}, \mathrm{brs}, 5^{\prime}\right), 3.69\left(1 \mathrm{H}, \mathrm{m}, 4^{\prime}\right), 4.15\left(1 \mathrm{H}, \mathrm{m}, 3^{\prime}\right), 5.14(3 \mathrm{H}$, $\left.b r, \mathrm{NH}_{2} \& \mathrm{OH}\right), 5.73(\mathrm{lH}, d, J=7.3 \mathrm{~Hz}, 5), 6.14\left(1 \mathrm{H}, t, J=6.7 \mathrm{~Hz}, \mathrm{l}^{\prime}\right), 7.31(2 \mathrm{H}, \mathrm{br}$, $\left.\mathrm{NH}_{2}\right), 7.72(1 \mathrm{H}, \mathrm{d}, \mathrm{J}=7.3 \mathrm{~Hz}, 6)$.

Yields $>100 \%$ are likely due to the incomplete removal of water.

BASIC PROTOCOL 4
$5^{\prime}$-Amino-2', $\mathbf{5}^{\prime}-$ Dideoxy-5'-N-

Triphosphate Nucleotides

\subsubsection{0}

\section{PREPARATION AND HPLC ANALYSIS OF $5^{\prime}$-AMINO-2', $5^{\prime}$-DIDEOXY $-5^{\prime}-N$-TRIPHOSPHATE NUCLEOTIDES}

This protocol describes a common procedure for synthesizing $\mathrm{NH}_{2}$-dNTPs from corresponding $\mathrm{NH}_{2}$-dNs. As shown in Figure 13.3.3, the procedure utilizes a facile reaction between primary amines and trisodium trimetaphosphate (TMP). This straightforward approach was previously applied for the preparation of $\mathrm{NH}_{2}$-dTTP with some success. However, the conversion yield was moderate and the product was unstable, which was likely caused by the inherently low stability of $\mathrm{NH}_{2}$-dTTP (Letsinger et al., 1976b). By adding a commonly used, sterically hindered primary amine (Tris) to the reaction mixtures, all four $\mathrm{NH}_{2}$-dNTPs have been prepared in dramatically improved yields (Wolfe et al., 2002). This protocol uses the preparation of $\mathrm{NH}_{2}$-dTTP as an example, and the reaction conditions and yields for other analogs are summarized in Table 13.3.2.

\section{Materials}

$\mathrm{NH}_{2}$-dA, $\mathrm{NH}_{2}-\mathrm{dC}, \mathrm{NH}_{2}$-dG (see Basic Protocol 3), and $\mathrm{NH}_{2}$-dT (Sigma)

Trisodium trimetaphosphate (TMP)

$0.5 \mathrm{M}$ aqueous Tris base

HPLC buffers A and B (see recipes)

$1.5-\mathrm{mL}$ microcentrifuge tubes

Vortex mixer

C18 column (Waters Nova-pak; $3.9 \times 150 \mathrm{~mm}, 4 \mu \mathrm{m}$ )

Additional reagents and equipment for HPLC (UNIT 10.5)

Table 13.3.2 Reagents and Conditions Used for the Synthesis of Each $\mathrm{NH}_{2}$-dNTP

\begin{tabular}{llllll}
\hline & $\begin{array}{l}\text { Nucleoside } \\
\text { (step 1) }\end{array}$ & TMP (step 1) & $\begin{array}{l}\text { 0.5 M Tris } \\
\text { base (step 2) }\end{array}$ & $\begin{array}{l}\text { Reaction time } \\
\text { (step 3) }\end{array}$ & $\begin{array}{l}\text { Conversion } \\
\text { yield by HPLC } \\
\text { (step 5) }\end{array}$ \\
\hline $\mathrm{NH}_{2}$-dATP & $47 \mu \mathrm{mol}$ & $234 \mu \mathrm{mol}$ & $468 \mu \mathrm{L}$ & 7 days & $85.6 \%$ \\
$\mathrm{NH}_{2}$-dCTP & $86 \mu \mathrm{mol}$ & $429 \mu \mathrm{mol}$ & $859 \mu \mathrm{L}$ & 5 days & $78.9 \%$ \\
$\mathrm{NH}_{2}$-dGTP & $86 \mu \mathrm{mol}$ & $430 \mu \mathrm{mol}$ & $860 \mu \mathrm{L}$ & 5 days & $83.2 \%$ \\
$\mathrm{NH}_{2}$-dTTP & $112 \mu \mathrm{mol}$ & $560 \mu \mathrm{mol}$ & $1120 \mu \mathrm{L}$ & 5 days & $91.5 \%$ \\
\hline
\end{tabular}

${ }^{a}$ For $\mathrm{NH}_{2}-\mathrm{dA}, \mathrm{NH}_{2}-\mathrm{dC}$, and $\mathrm{NH}_{2}-\mathrm{dG}$, the starting material quantities are based on the assumption that $\mathrm{N}_{3}-\mathrm{dN}$ was quantitatively converted to $\mathrm{NH}_{2}$-dN using Basic Protocol 3. 
1. Place $27.0 \mathrm{mg}(112 \mu \mathrm{mol})$ of $\mathrm{NH}_{2}$-dT and $171.4 \mathrm{mg}(560 \mu \mathrm{mol}, 5$ molar equiv.) TMP in a 1.5-mL microcentrifuge tube (also see Table 13.3.2).

2. Add $1120 \mu \mathrm{L}$ of $0.5 \mathrm{M}$ aqueous Tris base ( $560 \mu \mathrm{mol}, 5$ molar equiv.) to the tube and dissolve the solids using a vortex mixer.

3. Allow the resulting solution to stand 5 days at room temperature to generate $\mathrm{NH}_{2}$ dTTP.

The $100 \mathrm{mM} \mathrm{NH} \mathrm{H}_{2}-d N T P / 500 \mathrm{mM}$ Tris solutions (based on 100\% conversion) are used directly for experiments described in Basic Protocol 5. The following steps for HPLC analysis are optional. HPLC analysis is not necessary for application described in this unit and is recommended only when the knowledge of a specific conversion yield is deemed useful. The product is stable at room temperature and can be stored for weeks without losing activity. However, to avoid water loss and slow oxidation of Tris base, the mixture should be stored at $-20^{\circ} \mathrm{C}$ for a longer term (up to 1 year).

${ }^{31} P$ NMR spectra were recorded on a Bruker DPX-400 NMP spectrometer using $80 \%$ $\mathrm{H}_{3} \mathrm{PO}_{4}$ as an external standard. A doublet around -1 ppm was observed for all four triphosphate samples, corresponding to a phosphoramidate $(P \alpha-N)$ resonance. In all spectra the most prominent peak was at -21 ppm, corresponding to excess TMP. Due to excess TMP and its breakdown products, $P \beta$ and $P \gamma$ were not assigned. ${ }^{31} P$ NMR $\left(D_{2} O\right): N_{2}-d A T P,-0.99 \mathrm{ppm}(d, J=20.8 \mathrm{~Hz}) ; \mathrm{NH}_{2}-d C T P,-0.94 \mathrm{ppm}(d, J=19.5 \mathrm{~Hz})$; $\mathrm{NH}_{2}-d G T P,-1.00 \mathrm{ppm}(d, J=20.8 \mathrm{~Hz}) ; \mathrm{NH}_{2}-d T T P,-0.97 \mathrm{ppm}(d, J=20.1 \mathrm{~Hz})$.

4. Monitor the reaction mixture using an HPLC system equipped with a C18 column (UNIT 10.5). Elute the column with a mobile phase of HPLC buffers A and B at a flow rate of $1.00 \mathrm{~mL} / \mathrm{min}$. Vary the buffer gradient from $98 \%$ A to $100 \%$ B to achieve separation of $\mathrm{NH}_{2}$-dT from $\mathrm{NH}_{2}$-dTTP:

$\begin{array}{ll}0 \text { to } 8 \mathrm{~min} & 98 \% \text { A to } 70 \% \mathrm{~A} \\ 8 \text { to } 9 \mathrm{~min} & 70 \% \mathrm{~A} \text { to } 0 \% \mathrm{~A} \\ 9 \text { to } 10 \mathrm{~min} & 0 \% \mathrm{~A} \\ 10 \text { to } 11 \mathrm{~min} & 0 \% \mathrm{~A} \text { to } 98 \% \mathrm{~A} \\ 11 \text { to } 15 \mathrm{~min} & 98 \% \mathrm{~A} .\end{array}$

5. Compare peak areas corresponding to $\mathrm{NH}_{2}$ - $\mathrm{dT}$ (retention time $\approx 4.0 \mathrm{~min}$ ) and $\mathrm{NH}_{2}$ dTTP (retention time $\approx 10.7 \mathrm{~min}$ ) in the HPLC chromatograms to provide the yield of conversion $(91.5 \%)$.

Retention times for $\mathrm{NH}_{2}-d \mathrm{~A}$ and $\mathrm{NH}_{2}-d A T P: \approx 5.5 \mathrm{~min}$ and $\approx 14 \mathrm{~min}$, respectively; for $\mathrm{NH}_{2}-d C$ and $\mathrm{NH}_{2}-d C T P: \approx 2.0$ min and $\approx 5.0$ min, respectively; for $\mathrm{NH}_{2}-d G$ and $\mathrm{NH}_{2}-$ $d G T P \approx 3.0$ min and $\approx 10.5$ min, respectively.

\section{POLYMERASE INCORPORATION OF NH2-dNTPS}

This protocol describes procedures for incorporating each $\mathrm{NH}_{2}$-dNTP into DNA through a DNA polymerase-catalyzed template-directed primer extension reaction. The procedure is similar to routine primer extension reactions, with the exceptions that $\mathrm{NH}_{2}-\mathrm{dNTP}$ is used to replace or supplement its naturally occurring counterpart to afford complete or statistical analog substitution in the DNA product, respectively, and that an alkaline $\mathrm{pH}$ 9.5 buffer is used to improve the $\mathrm{NH}_{2}$ - $\mathrm{dNTP}$ stability. Among the many commercially available polymerases tested, Klenow polymerase ( $\mathrm{exO}^{-}$) provides the most efficient $\mathrm{NH}_{2}-$ $\mathrm{dNTP}$ incorporation. In this protocol, $\mathrm{NH}_{2}$-dNTPs are used in higher concentrations than those of native dNTPs to compensate for their reduced incorporation efficiency compared to dNTPs. Mild acid treatment of the substituted DNA product generates fragments that correspond to site-specific cleavage at each modified nucleotide, which provides direct evidence of successful $\mathrm{NH}_{2}$-dNTP incorporation as well as the sequence of the original DNA template (Wolfe et al., 2002).

BASIC

PROTOCOL 5

Nucleoside Phosphorylation and Related Modifications

\subsubsection{1}

Supplement 18 


\section{Materials}

$20 \mu \mathrm{M}$ oligonucleotide primer

$1.67 \mu \mathrm{M}\left[\gamma_{-}{ }^{32} \mathrm{P}\right] \mathrm{ATP}(6000 \mathrm{Ci} / \mathrm{mmol}$; Perkin-Elmer $)$

$10 \mathrm{U} / \mu \mathrm{L}$ T4 polynucleotide kinase and $10 \times$ buffer (New England Biolabs)

TE buffer, $\mathrm{pH} 8.0$ (APPENDIX 2A)

Single-stranded DNA templates: $\sim 100$ or 500 nucleotides in length (for complete or partial $\mathrm{NH}_{2}$-dNTP substitution, respectively)

$200 \mathrm{mM} \mathrm{MgCl} 2$

$500 \mathrm{mM}$ sodium acetate $(\mathrm{NaOAc})$

$10 \times$ polymerase extension buffers $\mathrm{A}$ and $\mathrm{B}$ (see recipes)

$100 \mathrm{mM} \mathrm{NH}_{2}$-dNTP solution(s) in 0.5 M Tris (see Basic Protocol 4)

2'-Deoxynucleoside triphosphates (dATP, dCTP, dGTP, dTTP)

$5 \mathrm{U} / \mu \mathrm{L}$ Klenow fragment of DNA polymerase ( $\mathrm{exo}^{-}$; New England Biolabs)

$1 \%$ and $10 \%(\mathrm{v} / \mathrm{v})$ acetic acid

Formamide loading buffer (Life Technologies)

Denaturing polyacrylamide gel mix and buffer solutions (National Diagnostics)

$1 \times$ TBE buffer (APPENDIX 2A)

10 mM EDTA, pH 8 (APPENDIX 2A)

0.5 -mL microcentrifuge tubes

Heat block at $37^{\circ}$ and $90^{\circ} \mathrm{C}$

Sephadex G-50 columns, preswollen in $\mathrm{dH}_{2} \mathrm{O}$

Speedvac evaporator

Additional reagents and equipment for polyacrylamide gel electrophoresis (PAGE; UNIT 10.4)

\section{Label and anneal oligonucleotide primer}

1. Label a primer using T4 polynucleotide kinase and $\left[\gamma_{-}{ }^{32} \mathrm{P}\right] \mathrm{ATP}$. In a $0.5-\mathrm{mL}$ microcentrifuge tube mix the following:

$1 \mu \mathrm{L} 20 \mu \mathrm{M}$ oligonucleotide primer

$1 \mu \mathrm{L} 1.67 \mu \mathrm{M}\left[\gamma_{-}^{-32} \mathrm{P}\right] \mathrm{ATP}(6000 \mathrm{Ci} / \mathrm{mmol})$

$1 \mu \mathrm{L} 10 \times \mathrm{T} 4$ polynucleotide kinase buffer

$6 \mu \mathrm{L} \mathrm{dH} \mathrm{H}_{2} \mathrm{O}$

$1 \mu \mathrm{L} 10 \mathrm{U} / \mu \mathrm{L}$ T4 polynucleotide kinase.

2. Incubate the mixture for 45 to $60 \mathrm{~min}$ at $37^{\circ} \mathrm{C}$.

3. Add $10 \mu \mathrm{L}$ TE buffer and purify the solution using a Sephadex G-50 column to afford an $\sim 1 \mu \mathrm{M}$ primer solution (assuming 100\% recovery).

Perform primer extension with complete $\mathrm{NH}_{2}$-dNTP substitution

4a. In a $0.5-\mathrm{mL}$ microcentrifuge tube mix the following:

$2 \mu \mathrm{L} \sim 1 \mu \mathrm{M}$ labeled primer

$10 \mu \mathrm{L} \sim 0.24 \mu \mathrm{M}$ ssDNA template ( $100 \mathrm{nt}$ in length)

$2 \mu \mathrm{L} 200 \mathrm{mM} \mathrm{MgCl}_{2}$

$2 \mu \mathrm{L} 500 \mathrm{mM}$ of $\mathrm{NaOAc}$

$4 \mu \mathrm{L} \mathrm{dH_{2 }} \mathrm{O}$.

$5^{\prime}-$ Amino-2, $5^{\prime}-$ Dideoxy-5'-N-

Triphosphate Nucleotides

13.3.12

5a. Heat the solution in a heat block 2 min at $90^{\circ} \mathrm{C}$, then allow the heat block to cool down to room temperature to afford a solution containing $\sim 0.1 \mathrm{M}$ DNA duplex in $20 \mathrm{mM} \mathrm{MgCl} / 2 / 50 \mathrm{mM} \mathrm{NaOAc}$. 
6a. In a $0.5-\mathrm{mL}$ microcentrifuge tube mix the following:

$1 \mu \mathrm{L}$ annealed DNA duplex solution

$1 \mu \mathrm{L} 10 \times$ polymerase extension buffer A

$1 \mu \mathrm{L} 100 \mathrm{mM}$ DTT

$0.4 \mu \mathrm{L} 100 \mathrm{mM} \mathrm{NH}_{2}$-dATP/0.5 M Tris (or other $\mathrm{NH}_{2}$-dNTP)

$1 \mu \mathrm{L} 1 \mathrm{mM}$ each dCTP/dGTP/dTTP (or any $3 \mathrm{dNTPs}$ that complement the $\mathrm{NH}_{2}$-dNTP)

$4.6 \mu \mathrm{L} \mathrm{dH_{2 } \mathrm { O }}$

$1 \mu \mathrm{L} 5 \mathrm{U} / \mu \mathrm{L}$ Klenow $\left(\mathrm{exo}^{-}\right)$DNA polymerase.

The resulting mixture contains $45 \mathrm{mM}$ Tris $\cdot \mathrm{Cl}$, pH 9.5, $10 \mathrm{mM} \mathrm{DTT,} 22 \mathrm{mM} \mathrm{MgCl}_{2}, 5 \mathrm{mM}$ $\mathrm{NaOAc}, 4 \mathrm{mM} \mathrm{NH} \mathrm{H}_{2}-d N T P, 0.1 \mathrm{mM}$ each of the other three dNTPs, and $5 \mathrm{U}$ Klenow (exo-) polymerase.

7a. Incubate $1 \mathrm{hr}$ at $37^{\circ} \mathrm{C}$.

8a. Add $30 \mu \mathrm{L}$ TE buffer and purify using Sephadex G-50 columns to afford $\sim 50 \mu \mathrm{L}$ of modified DNA solution. Store up to 2 weeks at $-20^{\circ} \mathrm{C}$.

Prepare G-50 columns using $\mathrm{G}-50$ resin preswollen in $\mathrm{dH}_{2} \mathrm{O}$. G-50 resin that has been pre-equilibrated in Tris buffers may alter the amount of acetic acid needed in step 9a.

\section{Perform site-specific cleavage at $\mathrm{NH}_{2}-\mathrm{dN}$ for complete substitution}

9a. In a $0.5-\mathrm{mL}$ microcentrifuge tube mix $8 \mu \mathrm{L}$ of each modified DNA solution with $2 \mu \mathrm{L}$ of $1 \%$ acetic acid and incubate $30 \mathrm{~min}$ at $37^{\circ}$ to $40^{\circ} \mathrm{C}$.

10a. Add $100 \mu \mathrm{L} \mathrm{dH_{2 }} \mathrm{O}$ to each sample, and concentrate the resulting solution to dryness on a Speedvac evaporator.

11a. Dissolve each sample in $\mathrm{dH}_{2} \mathrm{O}$. Adjust volume depending on the radioactivity of the samples.

12a. Transfer $2 \mu \mathrm{L}$ of each solution to another microcentrifuge tube and add $2 \mu \mathrm{L}$ formamide loading buffer.

13a. Analyze the samples by electrophoresing on a $12 \%$ denaturing polyacrylamide gel using standard procedures (UNIT 10.4) and $1 \times$ TBE buffer.

\section{Perform primer extension with partial (statistical) $\mathrm{NH}_{2}$-dNTP substitution}

4b. Anneal labeled primer to a ssDNA template as in steps 4a and 5a, but use a template that is $\sim 500 \mathrm{nt}$ in length.

5b. In a $0.5-\mathrm{mL}$ microcentrifuge tube mix the following:

$1 \mu \mathrm{L}$ annealed DNA duplex solution

$1 \mu \mathrm{L} 10 \times$ polymerase extension buffer B

$0.4 \mu \mathrm{L} 100 \mathrm{mM} \mathrm{NH}_{2}$-dATP/0.5 M Tris (or other $\mathrm{NH}_{2}$-dNTP)

$4 \mu \mathrm{L} 0.1 \mathrm{mM}$ dATP (or $2.6 \mu \mathrm{L} \mathrm{dCTP}, 1.6 \mu \mathrm{L}$ dGTP, $4.6 \mu \mathrm{L}$ dTTP)

$2 \mu \mathrm{L} 2 \mathrm{mM}$ each dCTP/dGTP/dTTP (or any $3 \mathrm{dNTPs}$ that complement the $\mathrm{NH}_{2}$-dNTP)

$\mathrm{dH}_{2} \mathrm{O}$ to $9 \mu \mathrm{L}$

$1 \mu \mathrm{L} 5 \mathrm{U} / \mu \mathrm{L}$ Klenow $\left(\mathrm{exo}^{-}\right)$DNA polymerase.

The resulting mixture contains $50 \mathrm{mM}$ Tris. $\mathrm{Cl}$, pH 9.5, $5 \mathrm{mM} \mathrm{DTT}, 22 \mathrm{mM} \mathrm{MgCl}, 5 \mathrm{mM}$ $\mathrm{NaOAc}, 4 \mathrm{mM} \mathrm{NH} \mathrm{H}_{2}$-dNTP, 0.016 to $0.046 \mathrm{mM}$ of the corresponding dNTP $(0.04 \mathrm{mM}$ dATP, $0.026 \mathrm{mM} d C T P, 0.016 \mathrm{mM} d G T P, 0.046 \mathrm{mM} T T P), 0.4 \mathrm{mM}$ each of the other three dNTPs, and 5 U of Klenow (exo-) polymerase.

Nucleoside Phosphorylation and Related Modifications

13.3.13 
6b. Incubate $1 \mathrm{hr}$ at $37^{\circ} \mathrm{C}$.

7b. Add $1 \mu \mathrm{L}$ of $1 \mathrm{mM}$ (each) dATP/dCTP/dGTP/dTTP and incubate for an additional 15 min at $37^{\circ} \mathrm{C}$.

8b. Add $20 \mu \mathrm{L}$ TE buffer and store the resulting solutions up to 2 weeks at $-20^{\circ} \mathrm{C}$.

\section{Perform site-specific cleavage at $\mathrm{NH}_{2}-\mathrm{dN}$ for partial substitution}

$9 \mathrm{~b}$. In a $0.5-\mathrm{mL}$ microcentrifuge tube mix the following:

$2 \mu \mathrm{L}$ modified DNA solution

$1 \mu \mathrm{L} 10 \mathrm{mM}$ EDTA, $\mathrm{pH} 8$

$6 \mu \mathrm{L} \mathrm{dH_{2 } \mathrm { O }}$

$1 \mu \mathrm{L} 10 \%$ acetic acid.

10b. Incubate $10 \mathrm{~min}$ at $37^{\circ} \mathrm{C}$.

11b. Proceed with analyis as in steps 10a to 13a.

\section{REAGENTS AND SOLUTIONS}

Use deionized, distilled water in all recipes and protocol steps. For common stock solutions, see APPENDIX 2A; for suppliers, see SUPPLIERS APPENDIX.

\section{HPLC buffer A}

Add $10 \mathrm{~mL}$ of $1 \mathrm{M}$ Tris. $\mathrm{Cl}$, $\mathrm{pH} 9$ (APPENDIX 2A), and $50 \mathrm{~mL}$ of $2 \mathrm{M}$ TEAA buffer

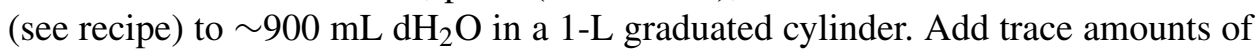
triethylamine and/or acetic acid to adjust the $\mathrm{pH}$ to 9 (measure using $\mathrm{pH}$ paper). Bring volume to $1 \mathrm{~L}$ with $\mathrm{dH}_{2} \mathrm{O}$ (final $10 \mathrm{mM}$ Tris/100 mM TEAA). Store up to several weeks at room temperature.

\section{HPLC buffer B}

Mix $750 \mathrm{~mL}$ HPLC buffer A (see recipe) and $250 \mathrm{~mL} \mathrm{MeOH}$. Store up to several weeks at room temperature.

Polymerase extension buffer A, $10 \times$

$0.25 \mathrm{M}$ Tris $\cdot \mathrm{Cl}, \mathrm{pH} 9.5$

$0.2 \mathrm{M} \mathrm{MgCl}_{2}$

Store up to several months at $-20^{\circ} \mathrm{C}$

Polymerase extension buffer $B, 10 \times$

$0.3 \mathrm{M}$ Tris. $\mathrm{Cl}, \mathrm{pH} 9.5$

$0.2 \mathrm{M} \mathrm{MgCl}_{2}$

$50 \mathrm{mM}$ dithiothreitol (DTT)

Store up to several months at $-20^{\circ} \mathrm{C}$

\section{TEAA (triethylammonium acetate) buffer, $2 \mathrm{M}$}

Chill triethylamine and acetic acid on ice. In a fume hood, mix $278.8 \mathrm{~mL}$ of triethylamine and $114.4 \mathrm{~mL}$ of acetic acid in a $1-\mathrm{L}$ graduated cylinder. $\mathrm{Add} \mathrm{dH}_{2} \mathrm{O}$ to $1 \mathrm{~L}$. Store up to several months at room temperature. 


\section{Background Information}

Due to their notably increased chemical reactivity and limited structural deviation from naturally occurring nucleosides, $5^{\prime}$ amino-2',5'-dideoxy nucleosides $\left(\mathrm{NH}_{2}\right.$-dNs) and nucleotides ( $\mathrm{NH}_{2}$-dNTPs) have been exploited for various applications. For example, derivatives of $\mathrm{NH}_{2}$-dT have been used for model studies on DNA replication (Luo et al., 1998), template-directed chemical amplification (Zhan and Lynn, 1997), mechanistic studies on polymerases and reverse transcriptases (Lutz et al., 1997), and the construction of combinatorial peptide-DNA hybrids (Bergmann and Bannwarth, 1995) and their libraries (Koppitz et al., 1998; Tetzlaff et al., 1998). In addition, $\mathrm{NH}_{2}$-dTTP and $\mathrm{NH}_{2}$ $\mathrm{dCTP}$ have been used to incorporate acid-labile phosphoramidate (P-N) linkers into DNA for high-throughput detection of single nucleotide polymorphisms using matrix-assisted fragmentation (Shchepinov et al., 2001), while $\mathrm{NH}_{2}$-dTTP has been applied in a dinucleotide DNA cleavage method developed for discovery of single nucleotide polymorphisms (Wolfe et al., 2003).

Most of the aforementioned applications have been demonstrated utilizing $\mathrm{NH}_{2}$-dT or its triphosphate $\mathrm{NH}_{2}$-dTTP, perhaps because $\mathrm{NH}_{2}$-dT is the only commercially available analog among the commonly used nucleosides and nucleotides. The ready availability of all four $\mathrm{NH}_{2}$-dNs and $\mathrm{NH}_{2}$-dNTPs will help expand the use of this class of compounds. The synthetic strategy described here takes advantage of common chemical features of all $\mathrm{NH}_{2}-$ dNTPs and utilizes synthetic methods including tosylation (also described in UNIT 13.2), azide exchange, and the Staudinger reaction. Because this approach does not require special equipment such as a Parr hydrogenation apparatus, these compounds can be conveniently made in many minimally equipped chemistry laboratories.

Besides polymerase incorporation of $\mathrm{NH}_{2}$ dNTPs, P-N linkers can also be introduced into DNA through solid-phase oligonucleotide synthesis using $5^{\prime}-\mathrm{NH}_{2}$-modified phosphoramidate building blocks (Mag and Engels, 1989; Shchepinov et al., 2001). This approach provides an opportunity to place P-N linkers at any specific position within an oligonucleotide, which is of importance for applications where predetermined localization of P-N bonds is desirable. However, solid-phase synthesis is not compatible with applications where limited DNA sequence information is available, as is the case for DNA sequence or polymorphism discovery (Wolfe et al., 2002, 2003). In addition, due to the lower efficiency of chemical coupling relative to enzymatic elongation, oligonucleotides generated by solid-phase synthesis have a very short length limit (up to $\sim 150$ bases) in comparison to replication reactions catalyzed by polymerases (up to several kilobases). For example, the authors have generated a 7.2-kb long $\mathrm{NH}_{2-}$ dT-containing polymerization product using Klenow $\left(\mathrm{exo}^{-}\right.$) polymerase and the M13 plasmid as template DNA (Wolfe et al., 2002). Furthermore, solid-phase synthesis requires access to an automated DNA synthesizer, as well as $5^{\prime}-\mathrm{NH}_{2}$-modified phosphoramidate building blocks that are not available commercially.

\section{Critical Parameters and Troubleshooting}

For chemical reactions described in Basic Protocols 1 through 3, it is critical to avoid moisture in all reaction mixtures. In the authors' experience, sealed bottles of anhydrous solvents obtained directly from vendors are sufficiently dry for these reactions. Starting material (nucleosides) should be routinely coevaporated with anhydrous solvents followed by vacuum drying before use.

In Basic Protocol 4, using a freshly prepared $0.5 \mathrm{M}$ Tris base solution will ensure sufficient buffering capacity. The $\mathrm{NH}_{2}$-dNTP products should be stored and used as prepared; isolation or dilution is not recommended because they may reduce the amount of $5^{\prime}-\mathrm{N}$-triphosphate nucleotides (Letsinger et al., 1976b). Although the concentration of the $\mathrm{NH}_{2}$-dNTP from individual attempted reactions may vary slightly, the overall reproducibility of this reaction is very high. HPLC analysis can provide information on the actual amount of the desired product, but is not required.

In Basic Protocol 5, the authors routinely use Klenow $\left(\mathrm{exo}^{-}\right)$polymerase from New England Biolabs. Polymerases from other vendors may also be applicable, but reaction conditions may need to be optimized since other polymerase products may have different enzymatic activities. Because the purity and concentration of each nucleotide may affect its polymerase incorporation efficiency, slight modifications of the $\mathrm{dNTP} / \mathrm{NH}_{2}$-dNTP ratios may be necessary for statistical incorporation
Nucleoside Phosphorylation and Related Modifications

\subsubsection{5}

Supplement 18 
experiments to achieve even incorporation of $\mathrm{NH}_{2}$-dNTPs.

The efficiency of acid cleavage reactions may be very sensitive to the amount of Tris in each DNA sample and the actual concentration of acetic acid used. Minor adjustments in acid concentration and/or reaction time may be necessary to accommodate these variations.

\section{Anticipated Results}

For Basic Protocols 1 through 3, the yields of chemical reactions are generally very high, although the recovered yield of purified products may be variable and considerably lower, depending on the scale or the method of purification.

Basic Protocol 4 is highly reproducible and the reaction mixtures can be directly used for downstream enzymatic reactions.

Polymerase incorporation of one of the $\mathrm{NH}_{2}$-dNTPs as complete replacement of its naturally occurring counterpart is very reproducible, as long as the Klenow (exo ${ }^{-}$) polymerase is fresh and relatively short DNA templates are used. Acid cleavage of these products may need to be optimized to achieve even cleavage bands.

Statistical incorporation of $\mathrm{NH}_{2}$-dNTPs and subsequent acid cleavage provide a sequencing ladder from long DNA templates. Using harsher cleavage conditions than described (i.e., higher concentration of acetic acid, longer reaction time, or higher temperature) will enrich shorter DNA fragments. Insufficient cleavage will enrich longer DNA fragments and the full-length extension product.

\section{Time Considerations}

The approximate time scale for the sequence of reactions and procedures described in this unit is 1 to 2 days for tosylation; 2 to 3 days for azidation and deprotection; 1 day for $\mathrm{Ph}_{3} \mathrm{P}$ reduction and hydrolysis; 5 to 7 days for triphosphate formation (mostly hands-off time); 2 days for annealing of primer to template, followed by polymerase incorporation of $\mathrm{NH}_{2} \mathrm{dNTPs}$ and subsequent chemical cleavage reactions; and 1 to 2 days for PAGE analysis of the products.

A major uncertainty in time consumption is related to column chromatography. The optimum solvent composition may depend on column diameter, quality of silica gel, purity of eluting solvents, and rate of elution. If removal of impurity is not completely successful in the first attempt, another column chromatography purification may be necessary.
Since HPLC analysis of $\mathrm{NH}_{2}$-dNTPs requires instrumentation and is time consuming, users may choose to skip this procedure. In the authors' experience, the preparation of $\mathrm{NH}_{2}$ dNTPs from $\mathrm{NH}_{2}-\mathrm{dNs}$ has been very reproducible.

\section{Literature Cited}

Bergmann, F. and Bannwarth, W. 1995. Solidphase synthesis of directly linked peptideoligodeoxynucleotide hybrids using standard synthesis protocols. Tetrahedron Lett. 36:18391842.

Koppitz, M., Nielsen, P.E., and Orgel, L.E. 1998. Formation of oligonucleotide-PNA-chimeras by template-directed ligation. J. Am. Chem. Soc. 120:4563-4569.

Letsinger, R.L., Hapke, B., Petersen, G.R., and Dumas, L.B. 1976a. Enzymatic synthesis of duplex circular phiX174 DNA containing phosphoramidate bonds in the (-) strand. Nucl. Acids Res. 3:1053-1063.

Letsinger, R.L., Wilkes, J.S., and Dumas, L.B. 1976b. Incorporation of 5'-amino-5'deoxythymidine- 5 '-phosphate in polynucleotides by use of DNA polymerase I and a phiX174 DNA template. Biochemistry 15:2810-2816.

Luo, P.Z., Leitzel, J.C., Zhan, Z.Y.J., and Lynn, D.G. 1998. Analysis of the structure and stability of a backbone-modified oligonucleotide: Implications for avoiding product inhibition in catalytic template-directed synthesis. J. Am. Chem. Soc. 120:3019-3031.

Lutz, M.J., Benner, S.A., Hein, S., Breipohl, G., and Uhlmann, E. 1997. Recognition of uncharged polyamide-linked nucleic acid analogs by DNA polymerases and reverse transcriptases. J. Am. Chem. Soc. 119:3177-3178.

Mag, M. and Engels, J.W. 1989. Synthesis and selective cleavage of oligodeoxyribonucleotides containing non-chiral internucleotide phosphoramidate linkages. Nucl. Acids Res. 17:59735988.

Mungal, W.S., Greene, G.L., Heavner, G.A., and Letsinger, R.L. 1975. Use of the azido group in the synthesis of $5^{\prime}$-terminal aminodeoxythymidine oligonucleotides. J. Org. Chem. 40:16591662.

Shchepinov, M.S., Denissenko, M.F., Smylie, K.J., Worl, R.J., Leppin, A.L., Cantor, C.R., and Rodi, C.P. 2001. Matrix-induced fragmentation of $\mathrm{P}^{\prime}-\mathrm{N}^{\prime}$ phosphoramidate-containing DNA: High-throughput MALDI-TOF analysis of genomic sequence polymorphisms. Nucl. Acids Res. 29:3864-3872.

Tetzlaff, C.N., Schwope, I., Bleczinski, C.F., Steinberg, J.A., and Richert, C. 1998. A convenient synthesis of $5^{\prime}$-amino-5'-deoxythymidine and preparation of peptide-DNA hybrids. Tetrahedron Lett. 39:4215-4218.

Wolfe, J.L., Kawate, T., Belenky, A., and Stanton, V. Jr. 2002. Synthesis and polymerase 
incorporation of $5^{\prime}$-amino-2 $2^{\prime}, 5^{\prime}$-dideoxy-5 $-\mathrm{N}$ triphosphate nucleotides. Nucl. Acids Res. 30:3739-3747.

Wolfe, J.L., Wang, B., Kawate, T., and Stanton, V.P. Jr. 2003. Sequence-specific dinucleotide cleavage promoted by synergistic interactions between neighboring modified nucleotides in DNA. J. Am. Chem. Soc. 125:10500-10501.

Yamamoto, I., Sekine, M., and Hata, T. 1980. Onestep synthesis of 5'-azido-nucleosides. J. Chem. Soc. Perkin I 306-310.

Zhan, Z.Y.J. and Lynn, D.G. 1997. Chemical amplification through template-directed synthesis. J. Am. Chem. Soc. 119:12420-12421.

Contributed by Jia Liu Wolfe and

Tomohiko Kawate

Massachusetts General Hospital

Cambridge, Massachusetts

Nucleoside

Phosphorylation

and Related

Modifications

13.3.17 